\title{
Pathogenic activities of live cells and extracellular products of the fish pathogen Pasteurella piscicida
}

\author{
B. Magariños, ${ }^{*}$ Y. Santos, J. L. Romalde, C. Rivas, J. L. Barja and A. E. Toranzo \\ Departamento de Microbiologia y Parasitologia, Facultad de Biologia, Universidad de Santiago de Compostela, Santiago \\ de Compostela 15706, Spain
}

(Received 8 June 1992; revised 17 August 1992; accepted 20 August 1992)

\begin{abstract}
The pathobiological activities in vivo and in vitro of live cells and extracellular products (ECP) of eleven Pasteurella piscicida strains of different origin were examined. Infectivity trials showed that $\boldsymbol{P}$. piscicida did not possess strict host specificity since the majority of the isolates were virulent for gilthead seabream, rainbow trout and turbot, with $\mathrm{LD}_{50}$ values ranging between $10^{3}$ and $10^{6}$ live cells. However, none of the strains tested were pathogenic for mice $\left(\mathrm{LD}_{50}>10^{8}\right.$ cells). In addition, the $\mathrm{ECP}$ were strongly toxic for fish $\left(\mathrm{LD}_{50}\right.$ ranging from 1.0 to $4.6 \mu \mathrm{g}$ protein per $\mathrm{g}$ fish), which clearly demonstrates their important role in the pathogenesis of pasteurellosis. All the ECP samples were cytotoxic for fish and homoiothermic cell lines, possessed notable phospholipase activity and displayed haemolytic activity for sheep, salmon and turbot erythrocytes (but not for trout erythrocytes). However, the production of proteolytic enzymes differed among the $P$. piscicida strains. Although no strain displayed elastase activity, five isolates (the Japanese and Italian strains) hydrolysed casein and gelatin. All these biological activities in vivo and in vitro were lost after heat treatment $\left(100{ }^{\circ} \mathrm{C}\right.$ for $\left.10 \mathrm{~min}\right)$. The general enzymic patterns of both live cells and ECP evaluated by the API-ZYM system also revealed some variation among the $P$. piscicida isolates. Generally, whole cells showed a wider range of enzymic activities than ECP. The results presented here are important for the selection of strains in the development of effective polyvalent pasteurellosis vaccines containing both whole cells and ECP.
\end{abstract}

\section{Introduction}

Pasteurella piscicida has been, since 1963, one of the most important halophilic bacterial pathogens, causing significant losses in wild and farmed fish in Japan (Kubota et al., 1970; Kimura \& Kitao, 1971; Kusuda \& Yamaoka, 1972; Ohnishi et al., 1982; Egusa, 1983; Yasunaga et al., 1984; Ueki et al., 1990) and the USA (Sniezsko et al., 1964; Paperna \& Zwerner, 1976; Robohm, 1979; Hawke et al., 1987). However, until 1990 there were no documented reports of fish pasteurellosis in Europe. Recently, we described the first pasteurellosis outbreak in juvenile gilthead seabream (Sparus aurata) cultured in the northwest of Spain (Toranzo et al., 1991). Simultaneously, epizootic outbreaks occurred in France and Italy, affecting mainly sea bass (Dicentrarchus labrax) and gilthead (Baudin-Laurencin et al., 1991; Ceschia et al., 1991). In addition, we have demonstrated (Toranzo et

\footnotetext{
* Author for correspondence.

Abbreviations: ECP, extracellular products; BHI, brain heart infusion; i.p., intraperitoneal(ly).
}

al., 1991; Magariños et al., 1991, 1992) that, regardless of their origin and source of isolation, all the European, Japanese and American $P$. piscicida strains examined shared similar biochemical, serological and molecular characteristics. However, in contrast with other substantiated fish pathogens, the mechanism of virulence of $P$. piscicida and the nature of factors involved in the pathogenesis of pasteurellosis have not been studied. To our knowledge, the present work represents the first analysis of the possible role of extracellular products (ECP) in the development of this disease. The biological activities present in the ECP from $P$. piscicida isolates of different geographic origins were evaluated in vivo and in vitro. In addition, the virulence of $P$. piscicida for different host species was determined.

\section{Methods}

Bacterial strains. Eleven $P$. piscicida strains, isolated from different fish species and geographical locations, were used (Table 1). For comparison, two pasteurellas from mammalian sources $(P$. multorida CECT 902 and $P$. haemolytica CECT 924) were also included. The taxonomic position of all the isolates was confirmed following the 
Table 1. Origin of Pasteurella isolates used.

\begin{tabular}{lll}
\hline \hline \multicolumn{1}{c}{ Strain } & \multicolumn{1}{c}{ Origin } & \multicolumn{1}{c}{ Donor* } \\
\hline P. piscicida & & \\
DI 21 & Sparus aurata (gilthead seabream), Spain & A. E Toranzo \& B. Magariños \\
DI 71 & Sparus aurata (gilthead seabream), Spain & A. E Toranzo \& B. Magariños \\
DI 91 & Sparus aurata (gilthead seabream), Spain & A. E Toranzo \& B. Magariños \\
10831 & Dicentrarchus labrax (sea bass), France & F. Baudin-Laurencin \\
IT-1 & Sparus aurata (gilthead seabream), Italy & G. Giorggetti \\
IT-2 & Sparus aurata (gilthead seabream), Italy & G. Giorggetti \\
MP-7801 & Seriola quinqueradiata (yellowtail), Japan & T. Kitao \\
MZS-8001 & Seriola quinqueradiata (yellowtail), Japan & T. Kitao \\
EPOY-8803-II & Epinephelus akaara (red grouper), Japan & K. Muroga \\
ATCC 17911 & Roccus americanus (white perch), USA & ATCC \\
ATCC 29690 & Seriola quinqueradiata (yellowtail), Japan & ATCC \\
P. haemolytica & & \\
CECT 924 & Ovine & CECT \\
P. multocida & & \\
CECT 902 & Bovine & CECT \\
\hline \hline
\end{tabular}

* Donor addresses: F. Baudin-Laurencin, Laboratoire National de Pathologie des Animaux Aquatiques, Brest, Plouzané, France; G. Giorgetti, Laboratorio di Ittiopatologia, Istituto Zooprofilattico Sperimentale delle Venezie, Italy; T. Kitao, Department of Fisheries, Faculty of Agriculture, Miyazaki University, Japan; K. Muroga, Faculty of Applied Biological Science, Hiroshima University, Japan; ATCC, American Type Culture Collection, Rockville, Maryland (USA); CECT, Colección Española de Cultivos Cultivos Tipo, Valencia, Spain.

procedures of West \& Colwell (1984), Fouz et al. (1990) and Toranzo et al. (1991). Serological characterization was performed by slide agglutination test as previously described (Toranzo et al., 1987a). Experimental cultures were prepared on Brain Heart Infusion Agar (BHIA, Difco) with $2 \%(w / v) ~ N a C l$ added (BHIA-2) from cultures stored frozen at $-70{ }^{\circ} \mathrm{C}$ in Tryptic Soy Broth (TSB, Difco) with $15 \%$ $(\mathrm{v} / \mathrm{v})$ glycerol. In the case of clinical pasteurellas the same culture medium without salt was employed.

In all the assays, strains Vibrio anguillarum R-82 and Aeromonas hydrophila B-32, which possess pathogenic activities for fish and mammals (Toranzo et al., 1987b; Santos et al., 1991 a) were used as controls.

Pathogenicity assays. In order to determine the host susceptibility range of $P$. piscicida, infectivity trials were conducted using different fish species and mice.

(i) Virulence for fish. The $50 \%$ lethal dose $\left(\mathrm{LD}_{50}\right)$ assays were performed by intraperitoneal (i.p.) injection as previously described (Toranzo et al., 1983a), using fingerling gilthead seabream $(8 \mathrm{~g})$, rainbow trout (Oncorhynchus mykiss) $(10 \mathrm{~g})$ and turbot (Scophthalmus maximus) $(5 \mathrm{~g})$. Groups of six fishes were inoculated i.p with bacterial doses ranging from $10^{2}$ to $10^{8}$ c.f.u. Control fish received $0.1 \mathrm{ml}$ phosphate-buffered saline (PBS, $\mathrm{pH} 7 \cdot 4$ ). Fish were maintained at $22^{\circ} \mathrm{C}$ with aeration during the course of the experiment (two weeks). The $\mathrm{LD}_{50}$ was calculated by the method of Reed \& Müench (1938). Fish surviving the challenge were killed and reisolation of the inoculated strain was attempted to test for the possible carrier state.

(ii) Mouse pathogenicity. To determine the degree of virulence of $P$. piscicida for homoiothermic animals, a mouse virulence assay was performed. Briefly, between 5 and 10 BALB/C mice (10-12 weeks old, 21-25 g) were inoculated i.p. with doses ranging from $10^{4}$ to $10^{8} \mathrm{c} . \mathrm{f}$.u. of each $P$. piscicida strain. Mortalities were recorded daily and the $L_{50}$ calculated $7 \mathrm{~d}$ after inoculation according to Reed \& Müench (1938). Strains displaying an $\mathrm{LD}_{50}<10^{7}$ c.f.u. were considered as virulent (Daily et al., 1981).

Preparation of the extracellular products (ECP) from the Pasteurella strains. The cellophane plate technique of Liu (1957) was used. Briefly, sterilized cellophane sheets were placed on the surface of BHIA plates and inoculated by spreading $0.5 \mathrm{ml}$ of a $24 \mathrm{~h}$ old broth culture of each strain with a sterile swab. The temperature of incubation was $22{ }^{\circ} \mathrm{C}(P$. piscicida) or $37^{\circ} \mathrm{C}$ (clinical pasteurellas). After incubation for $48 \mathrm{~h}$, cells were washed off the cellophane with a minimum volume of PBS. All the cell suspensions were centrifuged at $10000 \mathrm{~g}$ for $30 \mathrm{~min}$ at $4{ }^{\circ} \mathrm{C}$.

The supernatants were filtered through a $0.45 \mu \mathrm{m}$ pore-size membrane (Millipore), freeze-dried and reconstituted in PBS to a final volume of $10 \mathrm{ml}$. All ECP samples were stored at $-30^{\circ} \mathrm{C}$ until use. The protein concentration of each ECP sample was determined by the method of Bradford (1976), using bovine serum albumin as standard. The lipopolysaccharide (LPS) content of ECP was evaluated by the method of Keler \& Novotny (1986), using LPS from Escherichia coli serotype O128:B12 (Sigma) as standard.

Proteolytic, phospholipase and haemolytic activities. For the detection of the total proteolytic activity present in the ECP samples a general proteolytic substrate (Azocoll, Sigma) was employed. The assay was performed following the manufacturer's instructions (Sigma). One unit of protease activity produced an $\boldsymbol{A}_{520}$ reading of 1.0 after $30 \mathrm{~min}$ incubation at $37^{\circ} \mathrm{C}$.

Caseinase and gelatinase activities were determined by a radial diffusion method using a basal nutrient agar (BNA) (peptone, $4 \mathrm{~g} \mathrm{l}^{-1}$; yeast extract, $1 \mathrm{gl}^{-1}$; agar, $\left.15 \mathrm{gl}^{-1}\right)$ containing $1 \%(\mathrm{w} / \mathrm{v})$ sodium caseinate (Difco) or $1.5 \%(w / v)$ gelatin (Oxoid), respectively. Drops $(10 \mu \mathrm{l})$ of each ECP were placed on the plates and incubated at $22^{\circ} \mathrm{C}$ for 24-48 h. To enhance cleared zones, plates of gelatin were flooded with $15 \%(\mathrm{w} / \mathrm{v})$ mercuric chloride in $20 \%(\mathrm{v} / \mathrm{v}) \mathrm{HCl}$. One unit of caseinase or gelatinase activity was defined as that amount which produced a zone of clearing equal in area to that produced by $1 \mu \mathrm{g}$ trypsin (Sigma) (Bandin et al., 1991). Elastase activity was assayed on elastin medium (elastin, $1 \mathrm{gl}^{-1}$; yeast extract, $2 \mathrm{gl}^{-1}$; tryptone, $2 \mathrm{gl}^{-1}$; cysteine hydrochloride, $0.3 \mathrm{~g} \mathrm{l}^{-1}$; agar $15 \mathrm{~g} \mathrm{l}^{-1} ; 0.02 \mathrm{M}-\mathrm{Tris} / \mathrm{HCl}$; $\mathrm{pH} \mathrm{8.0)}$. Elastase activity was calculated as the reciprocal of the highest dilution of ECP producing elastin degradation after $72 \mathrm{~h}$ incubation. The production of phospholipase was quantified on plates of BNA containing $1 \%(\mathrm{v} / \mathrm{v})$ egg yolk emulsion (Oxoid). Plates were incubated for $48 \mathrm{~h}$, and the titre was defined as the reciprocal of the highest 
dilution of crude ECP producing opaque zones around the inoculum $(10 \mu \mathrm{l})$.

Haemolytic activity was evaluated by the standard radial diffusion method using BHIA medium with $5 \%(\mathrm{v} / \mathrm{v})$ sheep, trout or turbot erythrocytes added. One unit of haemolytic activity was defined as that which produced a zone of clearing equal in area to that produced by $0 \cdot 1 \%$ sodium dodecyl sulphate (SDS) (Bandín et al., 1991).

The general enzymic activities of the extracellular products and live cells of Pasteurella spp. were also evaluated by using the API-ZYM system (bioMérieux) at $22^{\circ} \mathrm{C}$ and following the manufacturer's instructions. The strips were incubated at $22^{\circ} \mathrm{C}\left(P\right.$. piscicida) or $37^{\circ} \mathrm{C}$ (clinical pasteurellas).

The stability of all these activities was assessed by assay after heating the ECP samples at $100^{\circ} \mathrm{C}$ for $10 \mathrm{~min}$.

Cytotoxicity assays. The ECP preparations were assayed for cytotoxicity as previously described (Toranzo et al., 1983b) in the following fish and homoiothermic cell lines: CHSE-214 (Chinook salmon embryo), RTG-2 (rainbow trout gonad), EPC (epithelioma papulosum cyprine), FHM (fathead minnow peduncle), HeLa (human cervix epithelioid) and Vero (African green monkey kidney). Monolayers grown in 24-well plates (Costar) were inoculated with $100 \mu \mathrm{l}$ of serial dilutions of each sample and incubated at $18^{\circ} \mathrm{C}$ (fish cell lines) or $37^{\circ} \mathrm{C}$ (homoiothermic cell lines). Total or partial destruction of monolayers within a $2 \mathrm{~d}$ period was considered as a positive cytotoxic effect. Results were expressed as the minimal amount of protein necessary to produce a cytotoxic response. Samples heated at $100{ }^{\circ} \mathrm{C}$ for $10 \mathrm{~min}$ were also tested.

Toxicity of ECP in vivo. The lethal effects of exotoxins produced by the $P$. piscicida strains for fish and mammals were evaluated in rainbow trout, turbot and mice by i.p. inoculation with $0.1 \mathrm{ml}$ of each preparation of ECP. Groups of six fish, maintained under the conditions described above for the virulence assays of live cells, were used per dose (serial twofold dilutions of the ECP). Mortalities were monitored over $7 \mathrm{~d}$ and the $\mathrm{LD}_{50}$ (expressed as $\mu \mathrm{g}$ ECP protein per $\mathrm{g}$ body weight of fish) was calculated by the method of Reed \& Müench (1938). In the case of mice, groups of between 5 and 10 animals were inoculated only with the undiluted ECP samples and the lethal effects expressed as number of dead mice/total number of inoculated animals. Control fish and mice were injected with $0.1 \mathrm{ml}$ PBS. The samples exhibiting lethal effects for fish or mice were also assayed after heating $\left(100{ }^{\circ} \mathrm{C}\right.$ for $\left.10 \mathrm{~min}\right)$.

Detection of vascular permeability factor. The presence in the ECP of dermonecrotic activity was determined as described by Olivier $e t$ al. (1981). Briefly, New Zealand White rabbits (1 kg body weight) were inoculated intradermally with $0.1 \mathrm{ml}$ of each ECP sample. Twenty hours after inoculation, the rabbits were killed and skinned. The presence of haemorrhagic and/or oedematous zones with a diameter greater than $0.8 \mathrm{~cm}$ was considered as a positive result. All the ECP were inoculated in triplicate and the standard deviation (SD) of the results was calculated. Positive samples were also inoculated after heating at $100^{\circ} \mathrm{C}$ for $10 \mathrm{~min}$.

\section{Results}

\section{Pathogenicity for fish and mammals}

To determine whether $P$. piscicida possesses host specificity, virulence assays were performed in different fish species and mice. With the exception of two strains (EPOY-8803-II and ATCC 29690), the P. piscicida isolates were virulent for gilthead seabream, rainbow trout and turbot with, $\mathrm{LD}_{50}$ values ranging from $10^{3}$ to $10^{6}$ cells (Table 2 ). Interestingly, trout and turbot proved to be the most susceptible species to pasteurellosis under laboratory conditions. Although, in general, no clinical signs were apparent in the moribund fish, the inoculated strains were always reisolated in pure culture from the internal organs of all dead fish. However, attempts to recover $P$. piscicida from surviving fish were unsuccessful.

The pathogenicity assays in mice demonstrated that none of the $P$. piscicida strains could be considered as virulent since they displayed $\mathrm{LD}_{50}$ values higher than $4 \times 10^{7}$ live cells (Table 2). Only the $P$. multocida isolate was pathogenic for mice, with an $\mathrm{LD}_{50}<2.0 \times 10^{3}$ cells. Therefore no relationship could be established between pathogenicity for fish and for mice in the Pasteurella species.

\section{Biological activities of the ECP in vitro}

The protein and LPS content of ECP from P . piscicida isolates was different depending on the extraction procedure. In general, all ECP obtained using the cellophane plate method showed notable levels of protein (0.3-3.4 $\mathrm{mg} \mathrm{m}^{-1}$ ) and LPS (0.9-2.3 $\mathrm{mg} \mathrm{ml}^{-1}$ ) (Table 3). The production of proteolytic enzymes differed among the strains since only the Japanese and Italian isolates were able to hydrolyse casein and gelatin. No strain exhibited elastase activity. However, all the ECP samples were cytotoxic for fish and homoiothermic cell lines, producing, in general, degenerative changes manifested by pyknotic nuclei, clusters of round cells, shrinking, dendritic elongations and finally cell detachment. The minimal amount of protein necessary to produce a cytotoxic response varied among the isolates and ranged from 0.09 $\mu \mathrm{g}$ ECP protein (Spanish, French and American strains) to $17 \mu \mathrm{g}$ (Japanese and Italian isolates). These results indicated no correlation between the proteolytic activities tested and cytotoxicity.

All the ECP from $P$. piscicida possessed notable phospholipase activity $\left(300-400 \mathrm{U} \mathrm{ml}^{-1}\right)$, which was not present in the clinical pasteurellas. However, the haemolytic activity was variable according to the erythrocytes employed. Whereas the majority of strains produced haemolysins against sheep and turbot erythrocytes, haemolytic activity for trout erythrocytes was not detected (Table 3).

The enzymic activities of the ECP of Pasteurella strains were also tested by using the API-ZYM system and the results were compared with the activities exhibited by the live cells (Table 4). In general, live cells of the different $P$. piscicida strains displayed a very similar pattern except for $\alpha$-glucosidase and $N$-acetyl- $\beta$ glucosaminidase activities. The $P$. piscicida live cells 
Table 2. Susceptibility of gilthead seabream, turbot and rainbow trout to live cells of $P$. piscicida.

\begin{tabular}{|c|c|c|c|c|}
\hline \multirow[b]{2}{*}{ Strain } & \multicolumn{3}{|c|}{ Virulence for fish $\left(\mathrm{LD}_{50}\right)^{*}$} & \multirow{2}{*}{$\begin{array}{l}\text { Pathogenicity } \\
\text { for mice } \\
\left(\mathrm{LD}_{50}\right)^{*}\end{array}$} \\
\hline & Seabream & Turbot & Trout & \\
\hline \multicolumn{5}{|l|}{$P$. piscicida } \\
\hline DI 21 & $+\left(1.6 \times 10^{5}\right)$ & $+\left(<1.6 \times 10^{4}\right)$ & $+\left(<6.3 \times 10^{3}\right)$ & $-\left(>2.0 \times 10^{8}\right)$ \\
\hline DI 71 & $+\left(2.1 \times 10^{5}\right)$ & $+\left(5.0 \times 10^{3}\right)$ & $+\left(<8.3 \times 10^{3}\right)$ & $-\left(>1.0 \times 10^{8}\right)$ \\
\hline DI 91 & $+\left(1.4 \times 10^{5}\right)$ & $+\left(<7.6 \times 10^{3}\right)$ & $+\left(<6.0 \times 10^{3}\right)$ & $-\left(>4.0 \times 10^{7}\right)$ \\
\hline 10831 & $+\left(8.2 \times 10^{4}\right)$ & $+\left(<4.7 \times 10^{3}\right)$ & $+\left(1.7 \times 10^{4}\right)$ & $-\left(>2.0 \times 10^{8}\right)$ \\
\hline IT-1 & $+\left(3.7 \times 10^{5}\right)$ & $+\left(<2.0 \times 10^{4}\right)$ & $+\left(2.3 \times 10^{4}\right)$ & $-\left(>2.0 \times 10^{8}\right)$ \\
\hline IT-2 & $+\left(3.0 \times 10^{5}\right)$ & $+\left(<3.0 \times 10^{4}\right)$ & $+\left(5.2 \times 10^{4}\right)$ & $-\left(>4.0 \times 10^{8}\right)$ \\
\hline MP-7801 & $+\left(1.0 \times 10^{5}\right)$ & $+\left(<5.0 \times 10^{3}\right)$ & $+\left(1.6 \times 10^{5}\right)$ & $-\left(>2.0 \times 10^{8}\right)$ \\
\hline MZS-8001 & $+\left(2.0 \times 10^{5}\right)$ & $+\left(<6.0 \times 10^{3}\right)$ & $+\left(1.2 \times 10^{5}\right)$ & $-\left(>3.0 \times 10^{8}\right)$ \\
\hline EPOY-8803-II & $-\left(>2.0 \times 10^{7}\right)$ & $-\left(>2.0 \times 10^{7}\right)$ & $-\left(>2.0 \times 10^{7}\right)$ & $-\left(>8.0 \times 10^{7}\right)$ \\
\hline ATCC 17911 & $(+)\left(4.7 \times 10^{6}\right)$ & $+\left(3.3 \times 10^{5}\right)$ & $(+)\left(3.1 \times 10^{6}\right)$ & $-\left(>2.0 \times 10^{8}\right)$ \\
\hline ATCC 29690 & $-\left(2.3 \times 10^{7}\right)$ & $-\left(>2.0 \times 10^{7}\right)$ & $-\left(>6.3 \times 10^{7}\right)$ & $-\left(>6.0 \times 10^{7}\right)$ \\
\hline \multicolumn{5}{|l|}{ P. haemolytica } \\
\hline CECT 924 & ND & ND & $-\left(>3.0 \times 10^{8}\right)$ & $-\left(>4.0 \times 10^{7}\right)$ \\
\hline \multicolumn{5}{|l|}{ P. multocida } \\
\hline CECT 902 & ND & ND & $-\left(>1.0 \times 10^{8}\right)$ & $+\left(<2.0 \times 10^{3}\right)$ \\
\hline \multirow{2}{*}{\multicolumn{5}{|c|}{$\begin{array}{l}\text { Controls } \\
\text { A. hydrophila }\end{array}$}} \\
\hline & & & & \\
\hline B-32 & ND & ND & $+\left(3.2 \times 10^{4}\right)$ & $+\left(1.0 \times 10^{6}\right)$ \\
\hline \multicolumn{5}{|l|}{$V$. anguillarum } \\
\hline R-82 & $+\left(7.3 \times 10^{5}\right)$ & $+\left(4.0 \times 10^{4}\right)$ & $+\left(8.0 \times 10^{2}\right)$ & $-\left(5.0 \times 10^{7}\right)$ \\
\hline
\end{tabular}

* Median lethal dose $50 \%\left(\mathrm{LD}_{50}\right)$ is expressed as the number of bacteria needed to kill $50 \%$ of inoculated animals. Symbols: + , virulent strain; -, avirulent strain; $(+)$ weakly virulent strain. ND, Not determined.

Table 3. Biological activities in vitro of the ECP from the Pasteurella strains obtained by the cellophane plate technique

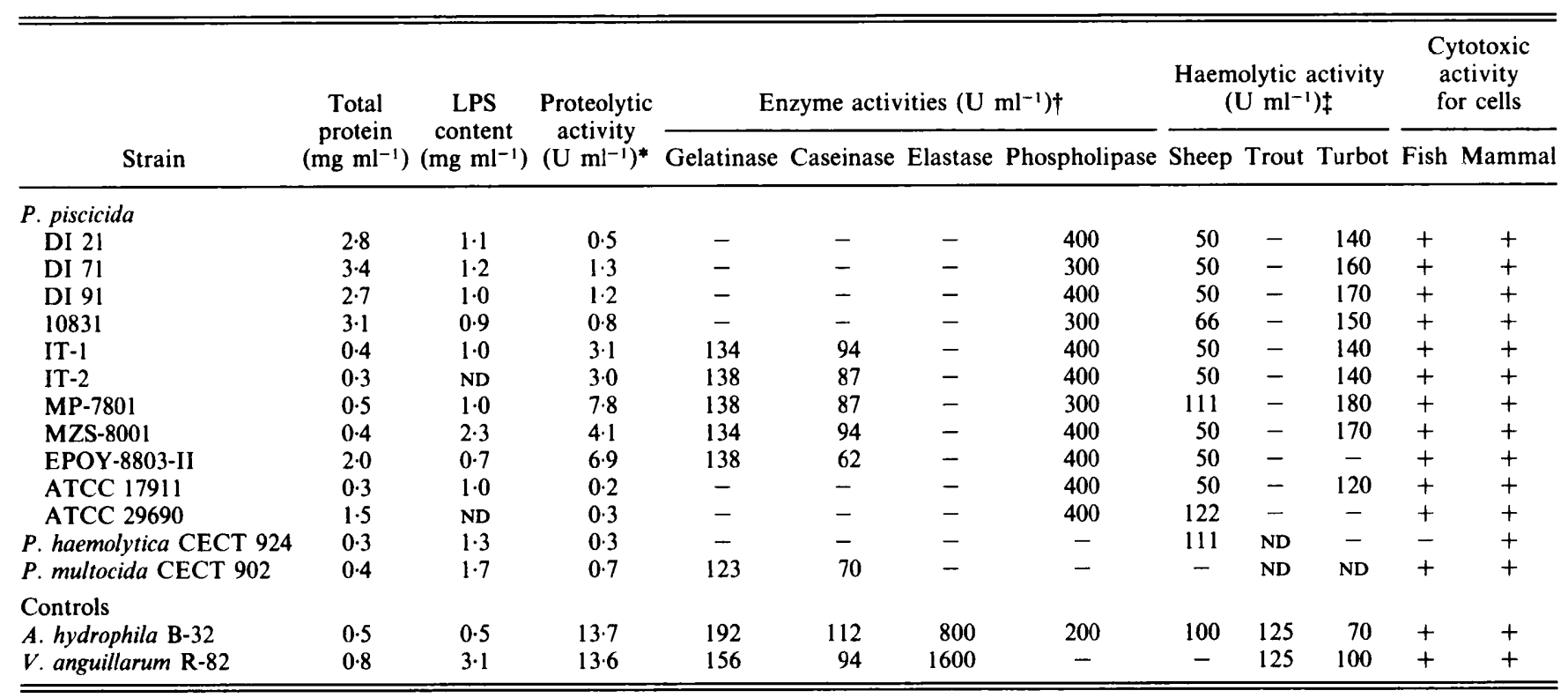

ND, Not determined.

* One unit of protease activity produced an $A_{520}$ reading of 1.0 after $30 \mathrm{~min}$ incubation at $37^{\circ} \mathrm{C}$.

$\dagger$ One unit of caseinase or gelatinase activity was defined as that which gave a zone of clearing equal in area to that produced by $1 \mu \mathrm{g}$ trypsin; one unit of phospholipase activity was expressed as the reciprocal of the highest dilution of crude ECP producing opaque zones; one unit of elastase was defined as the reciprocal of highest dilution producing elastin degradation.

$\ddagger$ One unit of haemolytic activity was expressed as that which gave a zone of clearing equal in area to that produced by $0 \cdot 1 \%$ SDS. 
Table 4. Enzyme activities displayed by live cells and ECP samples of Pasteurella strains

\begin{tabular}{|c|c|c|c|c|c|c|c|c|c|c|c|}
\hline \multirow{2}{*}{ Strain } & & \multicolumn{10}{|c|}{ Enzymic activities* } \\
\hline & & 2 & 3 & 4 & 6 & 10 & 11 & 12 & 13 & 16 & 18 \\
\hline \multicolumn{12}{|l|}{ P. piscicida } \\
\hline \multirow[t]{2}{*}{ DI 21} & Live cells & + & + & + & + & - & + & + & - & - & + \\
\hline & ECP & + & - & - & - & - & + & - & - & - & - \\
\hline \multirow[t]{2}{*}{ DI 71} & Live cells & + & + & + & + & - & + & + & - & - & + \\
\hline & ECP & + & - & - & - & - & + & - & - & - & - \\
\hline \multirow[t]{2}{*}{ DI 91} & Live cells & + & + & + & + & - & + & + & - & - & + \\
\hline & ECP & + & - & - & - & - & + & - & - & - & - \\
\hline \multirow[t]{2}{*}{10831} & Live cells & + & + & + & + & - & + & + & - & - & + \\
\hline & ECP & + & - & - & - & - & + & - & - & - & - \\
\hline \multirow[t]{2}{*}{ IT-1 } & Live cells & + & + & + & + & - & + & + & - & + & - \\
\hline & ECP & + & - & - & + & - & + & - & - & + & - \\
\hline \multirow[t]{2}{*}{ IT -2} & Live cells & + & + & + & + & - & + & + & - & + & - \\
\hline & ECP & + & - & - & + & - & + & - & - & + & - \\
\hline \multirow[t]{2}{*}{ MP 7801} & Live cells & + & + & + & + & - & + & + & - & - & + \\
\hline & ECP & + & - & - & - & - & + & - & - & - & - \\
\hline \multirow[t]{2}{*}{ MZS 8001} & Live cells & + & + & + & + & - & + & + & - & - & + \\
\hline & ECP & + & - & - & - & - & + & - & - & - & - \\
\hline \multirow[t]{2}{*}{ EPOY $8803-$ II } & Live cells & + & + & + & + & - & + & + & - & + & - \\
\hline & ECP & + & - & - & - & - & + & - & - & + & - \\
\hline \multirow[t]{2}{*}{ ATCC 17911} & Live cells & + & + & + & + & - & + & + & - & - & - \\
\hline & ECP & + & - & - & - & - & + & - & - & - & - \\
\hline \multirow[t]{2}{*}{ ATCC 29690} & Live cells & + & + & + & + & - & + & + & - & - & - \\
\hline & ECP & + & - & - & - & - & + & - & - & - & - \\
\hline \multirow{2}{*}{$\begin{array}{l}P \text {. haemolytica } \\
\text { CECT } 924\end{array}$} & Live cells & + & + & + & + & + & + & + & + & - & - \\
\hline & ECP & + & + & + & + & + & + & + & - & - & - \\
\hline \multirow{2}{*}{$\begin{array}{l}\text { P. multocida } \\
\text { CECT } 902\end{array}$} & Live cells & + & + & + & + & + & + & + & + & - & - \\
\hline & ECP & + & + & + & + & + & + & + & - & - & - \\
\hline
\end{tabular}

* Numbers indicate API code: 2 , alkaline phosphatase; 3, esterase; 4, esterase-lipase; 6 , leucine arylamidase; $10, \alpha$ chymotrypsin; 11, acid phosphatase; 12 , phosphoamidase; 13, $\alpha$-galactosidase; $16, \alpha$-glucosidase; $18, N$-acetyl- $\beta$ glucosaminidase. + , Positive response; - , negative response. All the strains failed to produce lipase, valine arylamidase, cystine arylamidase, trypsin, $\beta$-galactosidase, $\beta$-glucuronidase, $\beta$-glucosidase, $\alpha$-mannosidase and $\alpha$-fucosidase.

Table 5. Toxic activities for fish and mammals of ECP from Pasteurella strains

\begin{tabular}{|c|c|c|c|c|c|c|}
\hline \multirow[b]{2}{*}{ Strain } & \multicolumn{2}{|c|}{$\begin{array}{l}\text { Toxicity for fish } \\
\left(\mathrm{LD}_{50}\right)^{*}\end{array}$} & \multirow{2}{*}{$\begin{array}{l}\text { Time to death } \\
\text { of fish (h) }\end{array}$} & \multirow{2}{*}{$\begin{array}{l}\text { Toxicity } \\
\text { for mice } \dagger\end{array}$} & \multirow{2}{*}{$\begin{array}{l}\text { Time to death } \\
\text { of mice }(\mathrm{h})\end{array}$} & \multirow{2}{*}{$\begin{array}{l}\text { Dermonecrotic } \\
\text { factor } \ddagger\end{array}$} \\
\hline & Trout & Turbot & & & & \\
\hline \multicolumn{7}{|l|}{ P. piscicida } \\
\hline DI 21 & $+(3 \cdot 2)$ & $+(2.7)$ & $6-48$ & $+(5 / 6)$ & 24 & $+(1.6+0.2)$ \\
\hline DI 71 & $+(4 \cdot 5)$ & $+(3 \cdot 0)$ & $24-72$ & ND & ND & $+(1.2 \pm 0.3)$ \\
\hline DI 91 & $+(3 \cdot 1)$ & $+(2 \cdot 2)$ & $24-72$ & $+(5 / 6)$ & $6-24$ & $+(2.0 \pm 0.3)$ \\
\hline 10831 & $+(3 \cdot 6)$ & $+(2 \cdot 6)$ & 48 & $+(6 / 6)$ & 24 & $+(1.5+0.1)$ \\
\hline IT-1 & $+(4 \cdot 6)$ & $+(1.5)$ & $24-72$ & $+(5 / 6)$ & $24-48$ & $+(3.0 \pm 0.3)$ \\
\hline IT-2 & ND & $+(1.4)$ & $24-48$ & $+(6 / 6)$ & $24-48$ & ND \\
\hline MP-7801 & $+(1.7)$ & $+(1 \cdot 0)$ & $6-48$ & $+(6 / 6)$ & 6-24 & $+(2.5+0.3)$ \\
\hline MZS-8001 & $+(4 \cdot 1)$ & $+(1 \cdot 5)$ & $24-48$ & $+(6 / 6)$ & $6-24$ & - \\
\hline EPOY 8803-II & $+(4 \cdot 2)$ & $+(1 \cdot 6)$ & $6-24$ & $+(6 / 6)$ & $6-24$ & $+(3.0 \pm 0.3)$ \\
\hline ATCC 17911 & $+(3 \cdot 5)$ & $+(1.2)$ & $72-96$ & $+(5 / 6)$ & $24-48$ & - \\
\hline ATCC 29690 & $+(2 \cdot 5)$ & $+(1 \cdot 2)$ & $6-24$ & $+(6 / 6)$ & $24-48$ & - \\
\hline P. haemolytica CECT 924 & ND & ND & ND & $-(0 / 6)$ & NA & $+(3.0 \pm 0.4)$ \\
\hline P. multocida CECT 902 & - & - & NA & $-(0 / 6)$ & NA & - \\
\hline \multicolumn{7}{|l|}{ Controls } \\
\hline A. hydrophila B-32 & $+(2 \cdot 1)$ & ND & 6-8 & $+(6 / 6)$ & 6- 48 & $+(2 \cdot 5 \pm 0 \cdot 1)$ \\
\hline V. anguillarum $\mathrm{R}-82$ & $+(5.5)$ & ND & $6-8$ & $+(6 / 6)$ & $6-48$ & $+(2.8 \pm 0.2)$ \\
\hline
\end{tabular}

ND, Not determined; NA, not applicable.

* Median lethal dose $\left(\mathrm{LD}_{50}\right)$ is expressed as $\mu \mathrm{g}$ protein $(\mathrm{g} \text { fish })^{-1}$ needed to kill $50 \%$ of the inoculated fish.

$\dagger$ Number of mice dead/number of inoculated animals.

$\ddagger$ Oedematous and/or haemorrhagic areas greater than $0.8 \mathrm{~cm}$ in diameter were considered as a positive test result. Each sample was tested three times. 
always exhibited more activities than their respective ECP. In the majority of ECP samples, esterase, lipase, leucine arylamidase, phosphoamidase and $N$-acetyl- $\beta$ glucosaminidase activities were not detected. The live cells and ECP of $P$. multocida and $P$. haemolytica had an identical pattern but different from those exhibited by $P$. piscicida strains. In the ECP of clinical pasteurellas only the $\alpha$-galactosidase activity was absent (Table 4 ).

The proteolytic, cytotoxic, haemolytic and phospholipase activities of the ECP samples were all lost after heating at $100^{\circ} \mathrm{C}$ for $10 \mathrm{~min}$.

\section{Toxicity of the ECP for fish and mice}

The ECP from $P$. piscicida strains, extracted by the cellophane method, were strongly toxic for rainbow trout, causing mortality between 6 and $72 \mathrm{~h}$ after i.p. inoculation. In general, the $L D_{50}$ ranged from 1.7 to 4.6 (for trout) and from 1.0 to 3.0 (for turbot) $\mu \mathrm{g}$ protein ( $\mathrm{g}$ fish) $)^{-1}$ (Table 5). Similarly, all the ECP were lethal for mice and the mortalities occurred before $48 \mathrm{~h}$. In contrast, the ECP from clinical pasteurellas were not toxic for fish and mice. The lethal effects were lost after heating the ECP samples at $100^{\circ} \mathrm{C}$ for $10 \mathrm{~min}$.

\section{Presence of dermonecrotic factor}

In this assay, seven of the ten $P$. piscicida strains tested produced haemorraghic and/or oedematous zones at the inoculation site. Of the clinical pasteurellas, only the ECP from $P$. haemolytica isolate possessed dermonecrotic activity (Table 5). As with the other toxic and enzymic activities, dermatotoxicity was lost after heating.

\section{Discussion}

Hitherto, there have been no reports implicating the ECP of $P$. piscicida in the pathogenesis of the disease caused by this micro-organism. In this study, we examined the biological activities in vivo and in vitro of live cells and ECP of $P$. piscicida strains with different geographical origins and sources of isolation.

The virulence assays demonstrated that the majority of $P$. piscicida strains were pathogenic for all fish species challenged, with $\mathrm{LD}_{50}$ values ranging between $10^{3}$ and $10^{6}$ cells. It is important to note that, under laboratory conditions, the virulent strains were more pathogenic for turbot and rainbow trout than for seabream. Therefore, although $P$. piscicida did not seem to exhibit host specificity, we cannot rule out the possibility that the two nonvirulent strains for the fish species tested (EPOY-8803-II and ATCC 29690) can maintain their pathogenic capability for their original hosts (see Table 1). These results are in accordance with those obtained by Toranzo et al. (1987b) and Santos et al. (1991a) for Vibrio anguillarum and indicate that pasteurellosis may be a risk for marine fish species in which this disease has not been described. On the other hand, none of the strains can be considered as virulent for mice since they all displayed $\mathrm{LD}_{50}$ values greater than $10^{8}$ c.f.u.

Regarding ECP, we found that all the $P$. piscicida strains produced notable levels of extracellular proteins and LPS. In addition, all these ECP were lethal for turbot and trout, with $L_{50}$ values ranging from 1.0 to $4.6 \mu \mathrm{g}$ $\left(\mathrm{g}\right.$ fish) ${ }^{-1}$. These $\mathrm{LD}_{50}$ values are comparable to those reported for other fish pathogens such as Aeromonas (Thune et al., 1982; Ellis \& Stapleton, 1988; Santos, 1991; Santos et al., 1988) and Vibrio (Kodama et al., 1984; Inamura et al., 1985; Santos, 1991) or Serratia species (Baya et al., 1992).

A striking finding was that, although the $P$. piscicida strains were unable to proliferate within the homoiothermic host, all the ECP contained toxins with lethal effects for mice and, therefore, with a strong activity at $37^{\circ} \mathrm{C}$. However, not all the ECP tested possessed dermatotoxic activity when injected into rabbit skin. Therefore, in contrast to other fish pathogens such as Edwardsiella tarda (Ullah \& Arai, 1983) and Yersinia ruckeri (Romalde et al., 1992), dermatotoxins are not the most important virulence factors in $P$. piscicida. Interestingly, although the $P$. multocida strain was highly virulent for mammals $\left(L_{50}<10^{3}\right.$ live cells), its ECP had neither lethal effects for mice nor dermatotoxic activity in rabbits. In fact, it was recently reported that toxigenic strains of $P$. multocida produce a toxin (PMT) located in the cytoplasm which is not secreted by living intact cells (Idali et al., 1991).

The proteolytic activity of the ECP from $P$. piscicida was variable among the isolates, with no correlation with the total protein content. Moreover, only the Italian and most of the Japanese strains displayed gelatinase and caseinase activities. The use of the API ZYM system also revealed slight variations among the isolates. In addition, in this system the ECP displayed fewer enzymic activities than the live cells, which suggests that many of these activities were associated with the cell envelope or that some substrates were internalized.

Regardless of the origin of the cell lines (fish or mammals), all the ECP samples from $P$. piscicida showed cytotoxic effects. Therefore, no relationship exists between cytotoxins and the other enzymic activities tested. Similar results have been found in Vibrio anguillarum (Toranzo et al., 1983b), Yersinia ruckeri (Romalde et al., 1990) and Renibacterium salmoninarum (Bandín et al., 1991).

A common characteristic of all the ECP from $P$. 
piscicida (but not the other Pasteurella strains) was the presence of a thermolabile phospholipase activity. The role of phospholipases as the main extracellular toxin responsible for virulence has been clearly demonstrated in fish pathogens such as Aeromonas salmonicida (Lee \& Ellis, 1990), which produces a glycerophospholipid cholesterol acyltransferase (GCAT), and in the halophilic bacterium Vibrio damsela, which secretes a potent thermolabile cytolysin (damselysin) with phospholipase D activity (Kreger, 1984; Kreger et al., 1987).

All the biological activities of $P$. piscicida in vivo and in vitro were lost after heat treatment, which suggests that toxicity for fish and mammals is not solely associated with the LPS content of the ECP.

We have clearly demonstrated that the ECP from $P$. piscicida are involved in the pathogenesis of pasteurellosis when the bacteria have the capacity to successfully invade and proliferate in host tissues. In fact, it was reported in other fish pathogens (Allan \& Stevenson, 1981 ; Kodama et al., 1984; Chabot \& Thune, 1991; Ellis, 1991; Santos, 1991) that the biological activities present in the ECP can contribute in the development of the disease in terms of bacterial nutrition or as aggressins enabling the bacteria to counteract the host's defence systems.

In addition, although we have reported that $P$. piscicida constitutes a homogeneous phenotypic, serological and genetical taxon (Toranzo et al., 1991; Magariños et al., 1991, 1992), the present results indicated that the ECP composition differs among strains, which could be important for planning effective vaccination programmes. The results obtained in this work, and the fact that the use of whole cell bacterins is not very effective in the control of pasteurellosis outbreaks (Wakabayashi et al., 1977; Fukuda \& Kusuda, 1985; Hamaguchi \& Kusuda, 1989), suggest that the formulation of a polyvalent vaccine must include a mixture of whole cells and ECP. We have already demonstrated (Santos et al., $1991 b$ ) the efficacy of this type of vaccine in the control of vibriosis.

This investigation was supported by grant MAR 91-1133-C02-01 from the Comisión Interministerial de Ciencia y Tecnología (CICYT), Spain.

B. Magariños thanks the Conselleria de Educación, Xunta de Galicia, and C. Rivas the Ministerio de Educación y Ciencia (Spain), for Research Fellowships.

\section{References}

Allan, B. J. \& Stevenson, R. M. W. (1981). Extracellular virulence factors of Aeromonas hydrophila in fish infections. Canadian Journal of Microbiology 27, 1114-1122.

Bandín, I., Santos, Y., Bruno, D. W., Raynard, R. S., Toranzo, A. E. \& BARJA, J. L. (1991). Lack of biological activities in the extracellular products (ECP) of Renibacterium salmoninarum. Canadian Journal of Fisheries and Aquatic Science 48, 421-425.
Baudin-Laurencin, F., Pepin, J. F. \& Raymond, J. C. (1991). First observation of an epizootic of pasteurellosis in farmed and wild fish of the French Mediterranean coasts. In Abstracts, 5th International Conference of the European Association of Fish Pathologists (EAFP), Budapest, Hungary, p. 17.

Baya, A. M., Toranzo, A. E., Lupiani, B., Santos, Y. \& Hetrick, F. M. (1992). Serratia marcescens, a potential pathogen for fish. Journal of Fish Diseases 15, 15-16.

BRADFORD, M. M. (1976). A rapid and sensitive method for the quantitation of microgram quantities of protein utilizing the principle of protein-dye binding. Analytical Biochemistry 72, 248254.

Chabot, D. J. \& Thune, R. L. (1991). Proteases of the Aeromonas hydrophila complex : identification, characterization and relation to virulence in channel catfish, Ictalurus punctatus (Rafinesque). Journal of Fish Diseases 14, 171-183.

Ceschia, G., Quaglio, F., Giorgetti, G., Bertoja, G. \& Bovo, G. (1991). Serious outbreak of pasteurellosis (Pasteurella piscicida) in euryhaline species along the Italian coasts. In Abstracts, 5th International Conference of the European Association of Fish Pathologists (EAFP), Budapest, Hungary, p. 26.

Daily, O. P., Joseph, S. W., Coolbaugh, J. C., Walker, R. I., Merrell, B. R., Rollins, D. M., Seidler, R. J., Colwell, R. R. \& LISSER, C. R. (1981). Association of Aeromonas sobria with human infection. Journal of Clinical Microbiology 13, 265-277.

EguSA, S. (1983). Disease problems in Japanese yellowtail, Seriola quinqueradiata, culture: a review. In Diseases of Commercially Important Marine Fish and Shellish, pp. 10-18. Edited by J. E. Stewart. Copenhagen: Conseil International pour l' Exploration de la Mer.

ELLIS, A. E. (1991). An appraisal of the extracellular toxins of Aeromonas salmonicida sp. salmonicida. Journal of Fish Diseases 11, 309-323.

Ellis, A. E. \& Stapleton, K. J. (1988). Differential susceptibility of salmonid fishes to furunculosis correlates with differential serum enhancement of Aeromonas salmonicida extracellular protease activity. Microbial Pathogenesis 4, 299-304.

Fouz, B., Conchas, R. D., Bolinches, J., Romalde, J., BaRJa, J. L. \& TORANZo, A. E. (1990). Relationship among pathogenic Vibrio anguillarum and Vibrio tubiashi with environmental vibrios. In Pathology in Marine Science, pp. 77-89. Edited by F. O. Perkins \& T. C. Cheng. New York: Academic Press.

FUKUDA, Y. \& KUSUDA, R. (1985). Vaccination of yellowtail against pseudotuberculosis. Fish Pathology 20, 421-425.

HamaguCHI, M. \& KusUdA, R. (1989). Field testing of Pasteurella piscicida formalin killed bacterin against pseudotuberculosis in cultured yellowtail, Seriola quinqueradiata. Bulletin of Marine Sciences and Fisheries 11, 11-16.

Hawke, J. P., Plakas, S. M., Minton, S. M., McPhearson, R. M., SNIDER, T. G. \& GuARINo, M. (1987). Fish pasteurellosis of cultured striped bass, Morone saxatilis, in coastal Alabama. Aquaculture 65, 193-204.

Idali, C., Foged, N. T., Frandsen, P. L., Nielsen, M. H. \& Elling, F. (1991). Ultrastructural localization of the Pasteurella multocida toxin in a toxin-producing strain. Journal of General Microbiology 137, 1067-1071.

Inamura, H., Nakai, T. \& Muroga, K. (1985). An extracellular protease produced by Vibrio anguillarum. Bulletin of the Japanese Society of Scientific Fisheries 51, 1915-1920.

KELER, T. \& NovotNY, A. (1986). A metachromatic assay for the quantitative determination of bacterial endotoxin. Analytical Biochemistry 156, 189-193.

Kimura, M. \& KitaO, T. (1971). On the etiological agent of 'bacterial tuberculoidosis' of Seriola. Fish Pathology 6, 8-14.

Kodama, H., Moustafa, M., Ishiguro, S., Mikami, T. \& Izawa, H. (1984). Extracellular virulence factors of fish Vibrio: relationship between toxic material, hemolysin and proteolytic enzymes. American Journal of Veterinary Research 45, 2203-2207.

KREGER, A. S. (1984). Cytolytic activity and virulence of Vibrio damsela. Infection and Immunity 44, 326-331.

Kreger, A. S., Bernheimer, A. W., Etkin, L. A. \& Daniel, L. W. (1987). Phospholipase D activity of Vibrio damsela cytolysin and its 
interaction with sheep erythrocytes. Infection and Immunity 55, 32093212.

Kubota, S. S., Kimura, M. \& EguSa, S. (1970). Studies of a bacterial tuberculoidosis of the yellowtail. I. Symptomatology and histopathology. Fish Pathology 4, 111-118.

KusUdA, R. \& YAMAOKA, M. (1972). Etiological studies of bacterial pseudotuberculosis in cultured yellowtail with Pasteurella piscicida as the causative agent. I. On the morphological and biochemical properties. Bulletin of the Japanese Society of Scientific Fisheries 38, 1325-1332.

LiU, P. V. (1957). Survey of haemolysin production among species of Pseudomonas. Journal of Bacteriology 74, 718-727.

LeE, K. K. \& ELLIS, A. E. (1990). Glycerophospholipid cholesterol acyltransferase complexed with the lipopolysaccharide (LPS) is a major lethal exotoxin and cytolysin of Aeromonas salmonicida: LPS stabilizes and enhances toxicity of the enzyme. Journal of Bacterio$\operatorname{logy} 172,5382-5393$.

Magariños, B., Santos, Y., Fouz, B., Rivas, C. \& Toranzo, A. E. (1991). Studies on Pasteurella piscicida isolated in Spain. Abstracts, 5th International Conference of the European Association of Fish Pathologists (EAFP), Budapest, Hungary, p. 66.

Magariños, B., Romalde, J. L., Bandín, I., Fouz, B. \& Toranzo, A. E. (1992). Phenotypic, antigenic and molecular characterization of Pasteurella piscicida strains isolated from fish. Applied and Environmental Microbiology 58, 3316-3322.

Ohnishi, K., Sugiyama, T. \& Ueki, N. (1982). Pasteurella infection in young black seabream. Fish Pathology 16, 207-210.

Olivier, G., LALliER, R. \& LARIVIÈRE, S. (1981). A toxigenic profile of Aeromonas hydrophila and $A$. sobria isolated from fish. Canadian Journal of Microbiology 27, 330-333.

PAPERNA, I. \& ZWERner, D. E. (1976). Parasites and disease of striped bass, Morone saxatilis (Walbaum), from lower Chesapeake Bay. Journal of Fish Biology 9, 267-287.

ReED, L. J. \& MUENCH, H. (1938). A simple method of estimating fifty percent end points. American Journal of Hygiene 27, 493-497.

Roвонм, R. A. (1979). Pasteurella piscicida, the etiologic agent of an epizootic in striped bass (Morone saxatilis) in Long Island Sound. 4th Annual Eastern Fish Health Workshop, Halifax, NS, Canada, 25-27 June.

Romalde, J. L., Lemos, M. L., Conchas, R. F., Bandin, I. \& Toranzo, A. E. (1990). Adhesive properties and other virulence factors in Yersinia ruckeri. In Pathology in Marine Science, pp. 123-139. Edited by F. O. Perkins \& T. C. Cheng. New York: Academic Press.

Romalde, J. L., Santos, Y. \& Toranzo, A. E. (1992). Presence of skin permeability factors in the extracellular products of Yersinia ruckeri. Current Microbiology 24, 263-267.

SANTOS, Y. (1991). Factores de virulencia y caracteristicas antigénicas de Vibrio anguillarum y Aeromonas móviles. PhD thesis, University of Santiago, Spain.

Santos, Y., Toranzo, A. E., Barja, J. L., Nieto, T. P. \& Villa, T. G (1988). Virulence properties and enterotoxin production of Aeromonas strains isolated from fish. Infection and Immunity 56, 32853293.
Santos, Y., Lallier, R., Bandin, I., Lamas, J. \& Toranzo, A. E. (1991a). Susceptibility of turbot (Scophthalmus maximus), coho salmon (Oncorhynchus kisutch) and rainbow trout (O. mykiss) to the strains of Vibrio anguillarum and their exotoxins. Journal of Applied Ichthyology 7, 160-167.

Santos, Y., Bandin, I., Nuñez, S., Gravningen, K. \& Toranzo, A. E. $(1991 b)$. Protection of turbot, Scophthalmus maximus (L.), and rainbow trout, Oncorhynchus mykiss (Richardson), against vibriosis using two different vaccines. Journal of Fish Diseases 14, 407-411.

SNiezsKo, S. F., Bullock, G. L., Hollis, E. \& BooNE, J. G. (1964). Pasteurella sp. from a epizootic of white perch, Roccus americanus, in Chesapeake Bay tidewater areas. Journal of Bacteriology 88, 18141815.

Thune, R. L., Graham, T. E., Riddle, L. M. \& Amborski, R. L. (1982). Extracellular products and endotoxins from Aeromonas hydrophila: effects on age-0 channel catfish. Transactions of the American Fisheries Society 11, 749-754.

Toranzo, A. E., Barja, J. L., Potter, S. A., Colwell, R. R., HeTRICK, F. M. \& CrosA, J. H. (1983a). Molecular factors associated with virulence of marine vibrios isolated from striped bass in Chesapeake Bay. Infection and Immunity 39, 1220-1227.

Toranzo, A. E., Barja, J. L., Colwell, R. R., Hetrick, F. H. \& Crosa, J. H. (1983b). Haemagglutinating, haemolytic and cytotoxic activities of Vibrio anguillarum and related vibrios isolated from striped bass on the Atlantic coasts. FEMS Microbiology Letters 18, 257-262.

Toranzo, A. E., Baya, A. M., Roberson, B. S., Barja, J. L., Grimes, D. J. \& HeTRICK, F. M. (1987a). Specificity of the slide agglutination test for detecting bacterial fish pathogens. Aquaculture 61, 81-97.

Toranzo, A. E., Santos, Y., Lemos, M. L., Ledo, A. \& Bolinches, J. $(1987 b)$. Homology of Vibrio anguillarum strains causing epizootics in turbot, salmon and trout reared on the Atlantic coast of Spain. Aquaculture 67, 41-52.

Toranzo, A. E., Barreiro, S., Casal, J. F., Figueras, A., Magariños, B. \& BARJA, J. L. (1991). Pasteurellosis in cultured gilthead seabream, Sparus aurata: first report in Spain. Aquaculture 99, $1-15$.

Uexi, N., Kayano, Y. \& Muroga, K. (1990). Pasteurella piscicida in juvenile red grouper. Fish Pathology 25, 43-44.

Ullah, M. A. \& ARAI, T. (1983). Exotoxic substances produced by Edwardsiella tarda. Fish Pathology 18, 71-75.

WaKabayashi, H., TOYOTA, H. \& Egusa, S. (1977). Artificial infection of yellowtail with a gastral administration of cultured Pasteurella piscicida cells. Fish Pathology 11, 207-211

WEST, P. \& COLWELL, R. R. (1984). Identification and classification of Vibrionaceae. An over-view. In Vibrios in the Environment, pp. 285363. Edited by R. R. Colwell. New York: John Wiley.

YasunaGa, N., Yasumoto, S., Hirakawa, E. \& Tsukahara, J. (1984). On a massive mortality of oval file fish (Navodan modestus) caused by Pasteurella piscicida. Fish Pathology 19, 51-55. 